\title{
Repercussions of Globalization As Seen Through Diasporic Literature
}

\author{
${ }^{1}$ B. Sreekanth Reddy, ${ }^{2}$ Dr.P.Padma \\ ${ }^{1}$ Research Scholar JNTUA \\ ${ }^{2}$ Associate Prof. YVU Kadapa
}

\begin{abstract}
Globalisation though necessary for the all round development of a nation or individual but unconciously has brought out many controversial issues. It encouraged the people to migrate to western countries for a better life, economy, education, etc. In spite of the open economic system,new settlers confronted with the issues of inability to cope up with the traditions and culture of the alien land.The tecnological advancement brought alienation, uprootedness, lonliness. Due to this the concepts of marriage, intergenerational conflicts, cultural dilemmas have been challenged. An effort is made to bring to lime light the pain that the migrants feel. Many of the issues are often exposed by the diasporic writers. Most of them have actually experienced these issues of multiculturalism, nostalgia, inter-generational conflicts, familial. relations etc. An effort is made to expose these issues through the short stories as written by some diasporic writers.
\end{abstract}

Globalization opened up many avenues for the people of the world especially to the Eastern and third world countries. This aspect encouraged the people to migrate to the Western countries in search for better employment, economy, lifestyle, etc. Due to this phenomenon of migration and immigration, the terms like expatriate and diaspora gained popularity. The word diaspora literally means a scattering. Further categorization leads to the emergence of words such as immigrant, exile, refugee. Normally 'immigrant' defines a dislocation a physical movement whereas 'exile' indicates a compulsory isolation. These days many writers use the term 'expatriation' and 'immigration' as synonyms. But there is a thin line of demarcation between the two. Expatriation mainly focuses on the native land while immigration implies the country into which one has entered as an immigrant. We can also say that expatriate lives on his/her ex-status while the immigrant celebrates his/her present status in the host country. The expatriates are those who have nostalgia for the home country. This paper attempts to provide a bird's eye view of the life of the immigrants and also the different shades of experiences and responses of different individuals to different situations. The themes, the characters and the stories are thus a true reflection of the reality of globalization and immigrant life of the people in the alien country.

For the first generation, diaspora means strong feeling towards their homeland, and for the second generation, it means adjustment with the alien land, because the latter adopts himself / herself according to the norms of the accepted country. It becomes their country, yet not quite. They live at the juncture between the two cultures. Yet for reasons unknown they are born in one culture and they live in other culture, as a result they become marginalized. Marginality leads to the psychological conflicts of a divided self. With the loss of a sense of security of a known historical past and of a shared geographical space, their need to belong becomes the main issue. Most of the themes in diasporic literature reflect issues related to younger generation and their struggles, inter-generational relations, complexities of inter-racial relationships, the pinch of racism, etc. The younger generation growing up in America is exposed to two different cultures, one at home and the other at school and as a result, the younger generation experiences stress and identity crises.

The United States has always been a hub for immigrants. Many people from all corners of the world are migrating to this country. In this content the notion of identity and space in migrant writers works has drawn the attention of many critics and has become a solid matter of subject for exploration. Globalization has encouraged immigration for search of wealth, life style, education and many other aspects. The quest for different aspects of life changes with different generations of migrants. The first generation migrant stories focus on dislocation, poverty, racism, and the effects of cultural differences. But the second generation of migrants families suffer from multiculturalism, institutional discrimination. The second generation children who attend American schools are directly exposed to American culture, that questions their ideas, values, cultural and traditional values. The characters who are represented in diasporic literature always confront migrant experiences in the United States and they constantly negotiate between different aspects of their lives and recreate a third space that transcends the cultural and national boundaries. The notion of nation or national boundaries can't be nullified by the formation of transnational identity. Constructing a transnational identity means making a connection between different nations their people by overcoming their personal ideology. 
Due to globalization, the migrants confronted a number of issues and these issues are portrayed in the diasporic literatures. Literature as a product of culture becomes the source by which we understand and interpret the global multiculturalism. Indian immigrants form a large chunk of diaspora all over the world. Due to globalization, the potential of Indians has become more visible in the job market. The stories of immigration are of sweat and toil often washed with tears of achievements despite impediments of educational advancement and economic progress of political success at times. The catastrophic efforts of globalization can best be studied through a multidisciplinary approach. The study of the Indian diaspora in America opens up several themes and raises many issues which have relevance to an understanding of the multicultural experience from both countries point of view. The diasporic writings tells us about the hardships the immigrants have encountered before they got used to the alien traditions and culture. This doesn't mean that they have forgotten their homelands. Social identity depends on the sense of displacement, loss of home, nostalgia, tradition, culture, religion, ethnicity etc. Most of the immigrants write to cherish the past and also due to the fear of loss that makes them to preserve their ethnicity for the coming generations.

The expatriates who stay away from their motherland and still cling on to the past culture and traditions and there feelings are often exposed through the diasporic writers. In this sense the opinion of the writers of diaspora is an invaluable source of information to comprehend the diverse complexities of the expatriates. There is a need to realize and expose the cultural encounter, bi-cultural pulls existing among the individuals in the alien nation. Many writers have successfully portrayed the theme of diasporic elements through their literary works. A few among such writers are Bharathi Mukherjee, Chitra Banerjee Divakaruni, Jhumpa Lahiri, Amitav Ghosh, Arun Joshi, etc.

An overview of the short stories or novels written by them indicates that they focus strongly on the alienation and an overwhelming sense of nostalgia. This sense of nostalgia is enhanced as there is no antagonism towards the home society as they do not come to America or any other western country because of religious or political persecution at home. In the absence of a shared cultural heritage, the similarities disappear and the homeland acquires a romantic glow. This nostalgic feeling gives rise to many more issues such as marriages, familial relations, culture shocks, identity crises, racial discrimination, inter-generational conflicts, etc.

Of all the diasporic writers, Bharathi Mukherjee challenges the translucent lives of the immigrants especially that of the women, who are stable and strong in their characters but are emotionally not stable. Her novel 'Wife' personifies Dimple Dasgupta, as a 'psychoneuritic' before marriage and her problems get even more critical after her immigration to America. She feels that she suffers a strong sense of insecurity being a woman. She is confronted with diverse issues of multicultural aspects in the alien nation.

In the fast growing society, people of different nations, including Indians are migrating to the United States seeking better economic conditions. Today Indians belong to one of the fastest growing ethnic minorities in the U.S.A. As these immigrants are constantly exposed to multicultural issues, norms and values of western society, there is a rapid increase in the confusion regarding acculturation and assimilation. Western societies are not conducive to Indian tradition and the immigrants are forced to make adjustments according to the alien society. Many issues crop up due to this multiculturalism but only a few selected themes such as marriages, interpersonal relationships, inter-generational conflicts are taken up in this article.

\section{Marriage And Interpersonal Relationships}

Globalisation has greatly influenced the concept of marriage. Marriage binds families together and helps to maintain traditional customs. A marriage is considered as a union between two families and of two individuals, as it is in the western countries. According to the Hindu scriptures the marriage system in India was well established in the Vedic period. High value is given to the marriage system. According to them marriage is a means of maintaining regional, caste and families identity. Marriage is not just union of two individuals, but the blending of two families. The marriage system in America is quite different. In American society, the individual has more freedom of choice in issues related to selecting a life partner, love, marriage, dating and interrelationships. The American's view marriage as an agreement, the married couple sas a decision-making unit without any involvement or interference of relatives. Whereas the ideal Indian family believes in marriage as a sacred and social duty and a family responsibility, and stresses the importance of marital relationship.

But occasionally couples from diverse backgrounds are caught up in stifling relationship. The western concepts throws up more freedom but eastern concepts holds them back and ultimately the individuals in alien society are torn by these forces. The same concept is portrayed in Bharathi Mukherjee's novel - 'Wife', and Chitra Banerjee's short story - 'Doors'

Doors is an ironic title in Chitra Banerjee's collection of short stories from Arranged Marriage. Preeti is depicted as a person who always closes the doors behind her. The title is an image of the protagonist shutting out the emotions and attachments deep inside her. It can be observed that Preeti is not only found closing the 
doors of the room but also closing the doors of her heart against the marital relationship with her husband Deepak.

Preeti from India migrates to the United States during her childhood. She marries Deepak, her friend from the University. Her mother warns her to be careful with Deepak because she personifies herself as an immigrant wife who endures in transforming her life. She feels cynical about whether her daughter can adjust to the traditional married Indian life. Even Deepak's friends tease him during his marriage with Preeti - an American Indian women. This gives a perplexed feeling of Indian men about American Indian women. Indian men wish to marry Indian women who are more submissive than American Indian women. Preeti and Deepak's marital life runs smoothly with mutual love and respect thus shattering the old dogmas. But the arrival of Raj from India ruins their relationship. Raj stays in Deepak's house and Preeti doesn't appreciate their intimacy and develops a ense of envious sensitivity against Raj.

As Preeti was brought up in America could not digest or tolerate the degree of intimacy and affection between Deepak and Raj. Though an Indian, she was confused by the two traditions and cultures, one in which she was born and the other which she adapted. This aspect proves the impact of American society on a persons views on marital relationships. People like Preeti find themselves half-way between the traditional Indian values and the progressive American values. It proves that though Preeti was brought up in American society, she can't be completely westernized in her thoughts and feelings.

\section{Globalisation And Inter-Generational Conflicts}

Though the parents migrate for the development of their children, it is surprising to note the different types of conflicts that arise between the first and second generation immigrants. It is sometimes accepted that the second generation people are twice removed from their homeland. Sometimes they feel guilty of not being able to follow their culture, sometimes they experience the painful pinch of humiliation and of racism. They recall the trauma they went through particularly in schools and colleges where they were bullied. The second generation feels irritated when their parents insists them to follow Indian values and cultures. It is unrealistic to expect the second generation to follow the norms of their homeland. They are brought up in entirely different environment. They undergo the turmoil of hanging between the worlds. Mostly the parents fail to acknowledge the differences between the second generation. The western environment and culture create a sense of fear in parents. This fear makes them to control the second generation against their will. This becomes a nagging nuisance to the children who themselves are strangers to their original homelands. Most of the second generation immigrants tend to mould their lives living as Indians at home and as Americans outside, and this is not good for both the parents as well as for the children. Immigrant parents feel the real pressure of westernization in aspects of dating, sex marriage, patriarchal societies, etc. The above concepts are well reflected in the writings of Bharathi Mukherjee's short story, 'Father' in Darkness. In the story Mr. Bhowmick is a well disciplined man. He personally feels that in order to live comfortably certain matters should be planned first and later put into practice. Inspite of this ideology he is a failure both in his marital relationship and as a father. He fails to build and maintain good cordial relationship with his wifw and daughter. The women in his family were smarter than him, outgoing, cheerful and more American. He never had a positive not ion about his daughter but not the one who can comfront him. He never find her feminine either physically or mentally.

This shows that the first generation immigrants are uprooted, pushed far away, ill adapted to the cultural and traditional norms of the alien land. On the other hand the second generation masters the language, culture and ways of the new society. But the chidren adapt themselves at the cost of rejecting the parents, or atleast by subordinating them. The father is potrayed as a traditional man always clinging to the past customs in an alien world and as a person who can't digest the truth about his daughter. On a fine morning, he feels happy for her on being pregnant. He even tries to console himself with the fact of her not being married. He looks forward to play with his grandson.

This is a positive aspect of the story, when the father observes that his daughter is pregnant, he gets ready to accept it and awaits the gifts of a grandchild. He is not worried about the caste, creed of the man, but is just anxious to have a grandchild. This positive feeling suddenly turns to a brutal one when he hears that the cause of his daughter's pregnancy was artificial inseminisation and not a man. The daughter tells her father the father of her baby was a bottle and a syringe. She resorted to this method because she hated men. The father is shocked by this and he hits the daughter with a rolling pin on her stomach. This act proves that the father couldn't accept the reality. It reflects the strained relationship between the father and daughter. This incident portrays the younger generation as a 'problematic' section of the alien society who are confused with the two traditions. The modern culture has moulded Babli into a stubborn women who doesn't feel the need of a man. Babli never had any good interaction with her parents about her native culture and customs. She was born and brought up in America, the traditions of America made her independent and strong at the cost of emotional bonds and sensitivity with her parents. The story proves that girls like Babli are caught between rules and she 
was struggling between the traditiona and cultures of the homeland and hostland. While struggling to come out of this situation, they lose the emotional bonds.

B. Sreekanth Reddy. Research Scholar, JNTUA. AndhraPradesh 515002.

\section{References}

[1] Dhawan,R.K, ed. Writers of the Indian Diaspora. New Delhi: Prestige, 2001

[2] Divakaruni, Chitra Banerjee. London: Black Swan Transworld, 1997.

[3] Hall, Stuart.(1990). "Cultural Identity and Diaspora" Ed

[4] De, Shobha. Socialite Evenings. New Delhi: Penguin, 1988.

[5] Ashcroft, Bill, Gareth Griffiths, and Helen Tiffin. (1998). Key concepts in Post-colonial Studies: the key concepts. London: Routledge.

[6] Sireesha, Telugu, "Diasporic indian women writers" New Delhi: Prestige Books

Name: B. Sreekanth Reddy

\section{Bio Note}

Qualification's: M.A M.Ed M.Phil, (P.hd)

Experience: Seven years of teaching as a Lecturer in English in an Engineering college. Have conducted orientation classes for Teacher Trainers, Soft Skills and Personality Development sessions for freshers in various Engineering colleges

Areas of Interest: Experimentation with various pedagogical methods of teaching, usage of ICT in Lnaguage classrooms, Indian Diasporic studies. Have published nearly 10 research articles in well reputed international journals. .

\section{Declaration}

I, declare that the article entitled Repercussions of Globalization as seen through Diasporic Literature is an original work of mine.I have rightly acknowleged the primary sources. If there are any discripancies regarding the originality of the article I am solely responsible for it. 